\title{
Overexpression of HIF-1 $\alpha$ in primary gallbladder carcinoma and its relation to vasculogenic mimicry and unfavourable prognosis
}

\author{
WEI SUN ${ }^{1 *}$, ZHEN-YU SHEN $^{2 *}$, HUI ZHANG ${ }^{1 *}$, YUE-ZU FAN $^{1}$, \\ WEN-ZHONG ZHANG ${ }^{1}$, JING-TAO ZHANG ${ }^{1}$, XING-SUI LU ${ }^{1}$ and CHUN YE $^{1}$ \\ ${ }^{1}$ Department of Surgery, Tongji Hospital, Tongji University School of Medicine, Shanghai; \\ ${ }^{2}$ Department of Gastroenterology, Shanghai Tenth People's Hospital, Tongji University, Shanghai, P.R. China
}

Received December 14, 2011; Accepted February 28, 2012

DOI: $10.3892 /$ or.2012.1746

\begin{abstract}
As a novel mode of tumor neovascularization, vasculogenic mimicry (VM) has been reported to increase tumor-related mortality in many different solid tumors. In the present study, two established human gallbladder carcinoma (GBC) cell lines (highly aggressive GBC-SD and poorly aggressive SGC-996) cultured on a three-dimensional matrix were assessed for the ability of VM channel formation under normoxic or hypoxic conditions. In addition, the relationship between HIF-1 $\alpha$ gene expression and VM channel formation of GBC cells in vitro was measured using the small interfering RNA (siRNA) technique, western blotting and real-time reverse transcription (RT)-PCR analysis. Furthermore, H\&E and CD31/periodic acid-Schiff (PAS) staining were used to observe VM in GBC tissue samples. Additionally, all seventy-one specimens with VM and non-VM were stained for hypoxia inducible factor- $1 \alpha(\mathrm{HIF}-1 \alpha)$ and its correlation with clinicopathological features and prognosis was analyzed simultaneously. We found that hypoxia could induce more VM channel formation and elevated HIF-1 $\alpha$ expression in highly aggressive GBC-SD cells. HIF-1 $\alpha$ siRNA efficiently knocked down HIF-1 $\alpha$ expression and GBC VM networks under either normoxic or hypoxic conditions. VM was present in human primary GBC and overexpression of HIF-1 $\alpha$ was significantly correlated with depth of invasion and perineural involvement in the non-VM group. Moreover, VM and HIF-1 $\alpha$ were independent factors for the overall survival of GBC patients and correlated with decreased survival. In conclusion, VM was
\end{abstract}

Correspondence to: Professor Yue-Zu Fan, Department of Surgery, Tongji Hospital, Tongji University School of Medicine, 389 Xincun Road, Shanghai 200065, P.R. China

E-mail: fanyuezu_shtj@yahoo.com.cn

${ }^{*}$ Contributed equally

Key words: vasculogenic mimicry, hypoxia inducible factor-1 $\alpha$, gallbladder neoplasm, prognosis present in human GBC. As a critical mediator in VM formation, high expression of HIF-1 $\alpha$ was associated with VM and tumor progression in GBC patients.

\section{Introduction}

Gallbladder carcinoma (GBC) is one of the most common malignant biliary tumors and the sixth most common gastrointestinal cancer diagnosed in USA (1). Epidemiological data showed the incidence of GBC has been rising steeply in Shanghai, China $(2,3)$. GBC is a highly malignant digestive tumor with a very poor prognosis $(4,5)$. However, to date, the molecular mechanism of its development and progression, and special biological behavior remains poorly understood $(4,6)$.

Vasculogenic mimicry (VM), which is different from angiogenesis and mosaic vessel, is an alternative type of blood supplement formed by highly invasive and genetically deregulated tumor cells with a pluripotent embryonic-like genotype (7). The VM channels are formed by tumor cells, and have a basement membrane that stains positive with periodic acid-Schiff (PAS) reagent. In addition, VM might serve as another mechanism by which tumor cells could obtain nutrients to survive, especially in the less vascularized areas of the tumor (8). Recently, two distinctive types of VM have been described, such as the tube (a PAS-positive pattern) and patterned matrix types (9). After these initial observations in melanoma $(7,10)$, evidence for VM has been reported in other types of human cancers, including renal cell carcinoma (11) breast cancer (12), ovarian carcinoma (13), hepatocellular carcinoma (HCC) (14), laryngeal squamous cell carcinoma (LSCC) (15), glioblastomas (16), gastric adenocarcinoma (17) and colorectal cancer (18). Furthermore, tumors exhibiting VM related to more aggressive tumor biology and increased tumor-related mortality $(10,11,19)$.

Hypoxia inducible factor-1 (HIF-1) is the major transcription factor involved in the adaptive response to hypoxia and consists of HIF- $1 \alpha$ and HIF- $1 \beta$ subunits (20). HIF- $1 \alpha$ is targeted for ubiquitin-mediated degradation by the Von Hipple-Lindau (VHL) protein under normoxic conditions and is quickly degraded by proteasomes. However, HIF-1 $\alpha$ expression in hypoxia can escape proteasome degradation. In 
response to hypoxia in a hypovascular environment, HIF-1 $\alpha$ protein accumulates in the cytosol and translocates to the nucleus, where it activates hypoxia-sensitive genes, such as vascular endothelial growth factor (VEGF), by binding to their promoter regions (21). Interestingly, the human melanoma with VM remained non-necrotic even though the diameter of the tumor was $>10 \mathrm{~mm}^{3}$ (22). Moreover, recent observations have indicated that HIF-1 $\alpha$ protein could be the crucial factor for the formation of VM in several tumor types (23-28). Besides the GBC-SD cell lines in China, the human primary GBC cell lines SGC-996, isolated from the primary mastoid adenocarcinoma of the gallbladder obtained from a 61-yearold female patient in Tongji Hospital, were successfully established by our groups in 2003. Furthermore, SGC-996 cells were in accordance with the general characteristic of the cell line in vivo and in vitro and applied in several laboratory investigations $(29,30)$. Our groups have shown evidence of VM in three-dimensional matrix of highly aggressive GBC-SD or poorly aggressive SGC-996 cells preconditioned by highly aggressive GBC-SD cells in vitro and GBC-SD nude mouse xenografts in vivo (31). However, scarce data are available on the clinical value and important role of HIF-1 $\alpha$ in VM channel formation in GBC.

The primary objective of this study was to investigate the potential role of HIF-1 $\alpha$ in VM channels formation of GBC-SD and SGC-996 cells under normoxic or hypoxic conditions by using HIF-1 $\alpha$ knockout technique, western blotting and realtime reverse transcription-PCR analysis. A further objective was to explore the evidence of VM in GBC tissue samples and also evaluate the clinical significance of HIF-1 $\alpha$ in primary GBC patients with VM and non-VM by immunohistochemical analysis.

\section{Materials and methods}

Three-dimensional matrigel culture under normoxic or hypoxic conditions. Two established human GBC cell lines used in this study were highly aggressive GBC-SD cells (Shanghai Cell Biology Research Institute of Chinese Academy of Sciences, CAS, China) and poorly aggressive SGC-996 cells (a generous gift from Dr Yao-Qing Yang, Tumor Cell Biology Research Institute of Tongji University, China). A 24-well tissue culture plate was coated with $50 \mu \mathrm{l} /$ well cold Matrigel (Becton-Dickinson, Franklin Lakes, NJ, USA), which was allowed to polymerize for $30 \mathrm{~min}$ at room temperature, then $30 \mathrm{~min}$ at $37^{\circ} \mathrm{C}$ in a humidified $5 \%$ carbon dioxide incubator. The cells $\left(5 \times 10^{5}\right)$ were then seeded onto the gels and incubated at $37^{\circ} \mathrm{C}$ with $5 \%$ carbon dioxide and humidity. The cells were maintained in Dulbecco's modified Eagle's media (DMEM, Gibco Co., Grand Island, NY, USA) supplemented with $10 \%$ fetal bovine serum (FBS, Hangzhou Sijiqing Bioproducts, China) and $0.1 \%$ gentamicin sulfate (Gemini Bioproducts, Calabasas, CA, USA). Culture medium was changed every 2-3 days. The cells were grown to $50 \%$ confluent and then cultured for $48 \mathrm{~h}$ under normoxic $\left(20 \% \mathrm{O}_{2}\right.$, $5 \% \mathrm{CO}_{2}$, and $\left.75 \% \mathrm{~N}_{2}\right)$ or hypoxic $\left(2 \% \mathrm{O}_{2}, 2 \% \mathrm{CO}_{2}\right.$, balanced of nitrogen) conditions provided by a gas mixture tank (Wilson Medical Gases Inc., MI, USA) before analysis. Images of VM channels were taken digitally using a Zeiss Televal inverted phase-contrast microscope (Carl Zeiss, Inc., Thornwood, NY,
USA) and camera (Nikon, Japan) at the time indicated. Total RNA and cell lysates were collected for western blotting and real-time RT-PCR analysis, respectively.

$H I F-1 \alpha$ silencing with small interfering RNA (siRNA). Small interfering RNA targeted HIF-1 $\alpha$ (sense 5'-UCA AGU UGC UGG UCA UCA GdTdT-3'; antisense 5'-CUG AUG ACC AGG AAC UUG AdTdT-3') and control siRNA not targeting any known genes (5'-ACT ACC GTT GTT ATA GGT G-3') were synthesized and annealed (Dharmacon Research, Inc., Lafayette, CO, USA) as previously described (32). GBC-SD and SGC-996 cells were plated, respectively, in 6-well tissue culture plate at $5 \times 10^{5}$ cells per well $48 \mathrm{~h}$ under normoxic or hypoxic conditions before transfection. Before transfection for GBC-SD cells, the medium was replaced with $2 \mathrm{ml}$ of antibiotic-free medium and then cells were transfected at a final siRNA duplex concentration of 80 pmol using Lipofectamine ${ }^{\mathrm{TM}}$ 2000 (Invitrogen) according to the manufacturer's protocol. Transfection mixtures were incubated with cells for $8 \mathrm{~h}$ before washing with media and incubated for additional time period to equal total incubation time of $24 \mathrm{~h}$. The interference of HIF-1 $\alpha$ protein expression was confirmed by western blotting and real-time RT-PCR analysis. In addition, some transfected cells were harvested and used for three-dimensional culture assay to explore the VM channels.

Western blot analysis. Two established human GBC cell lines (GBC-SD and SGC-996) were lysed in RIPA butter for $5 \mathrm{~min}$. After removal of cell debris by centrifugation $(12,000 \mathrm{~g}$, $10 \mathrm{~min}$ ). Using the bicinchoninic acid protein assy kit, protein concentrations were quantified and $30 \mu \mathrm{g}$ of protein per sample was separated onto a denaturing SDS-polyacrylamide gel (PAGE), and transferred onto PVDF membrane. After having been blocked with $5 \%$ non-fat milk for $1 \mathrm{~h}$. Primary antibodies, anti-HIF-1 $\alpha$ (dilution 1:500, Sigma), were diluted in the buffer and incubated overnight at $4^{\circ} \mathrm{C}$ with gentle agitation. After subsequently washed with TBST, the membranes were incubated with secondary antibody (horseradish peroxidase-conjugated anti-rabbit) for $1 \mathrm{~h}$ at room temperature. The experiment was repeated in triplicate. Reactive protein was detected using ECL chemiluminescence system (Pierce, Rockford, USA). The amount of each protein sample was normalized with $\beta$-actin (Sigma).

Real-time reverse transcription (RT)-PCR analysis. Total RNA from cultured cells was extracted using the TRIzol reagent (Invitrogen) and isolated according to the manufacturer's instruction. The first strand cDNA was synthesized according to the manufacturer's instructions (Takara RT kit, Japan). Quantitative determination of HIF-1 $\alpha$ transcript concentrations was performed by real-time RT-PCR with GAPDH as an internal control. Primers for HIF-1 $\alpha$ (sense 5'-TCA TCC AAG AAG CCC TAA CGT G-3'; antisense 5'-TTT CGC TTT CTC TGA GCA TTC TG-3') and GAPDH (sense 5'-GAG TCA ACG GAT TTG GTC GT-3'; antisense 5'-TTG ATT TTG GAG GGA TCT CG-3') synthesized by Sangon Biotech (Shanghai, China) and were used to measure gene expression. We used SYBR ExScript ${ }^{\mathrm{TM}}$ RT-PCR kit (Takara, Japan) and ABI Prism ${ }^{\circledR} 7900 \mathrm{HT}$ sequence detection system. The regents went through a phase of $95^{\circ} \mathrm{C}$ for $30 \mathrm{sec}$ 
and were then cycled 40 times of $95^{\circ} \mathrm{C}$ for $5 \mathrm{sec}$ and $60^{\circ} \mathrm{C}$ for $15 \mathrm{sec}$ and $72^{\circ} \mathrm{C}$ for $30 \mathrm{sec}$. Real-time PCR was then employed to determine the fold of increase of HIF-1 $\alpha$ mRNA in established human GBC-SD and SGC-996 cell lines. Expression data were normalized to the geometric mean of housekeeping gene GAPDH to control the variability in expression levels and analyzed using the $2^{-\Delta \Delta \mathrm{Ct}}$ method $[\Delta \Delta \mathrm{Ct}=\mathrm{Ct}(\mathrm{HIF}-1 \alpha)$ $\mathrm{Ct}(\mathrm{GAPDH})]$, where $\mathrm{C}_{\mathrm{T}}$ represents the threshold cycle for each transcript.

Patients and tissue specimens. During May 1999 and June 2006, 71 patients who underwent curative surgical resection for primary gallbladder carcinoma (GBC) in Shanghai Tongji Hospital of Tongji University were included in the present study. Written informed consent was obtained from all patients, and the Ethics Committee of Tongji University approved the study. To reduce effects directly related to surgery, patients who died within one month after surgical resection were not included. None of the patients with GBC received chemotherapy or radiotherapy before surgery.

All 71 resection specimens with complete clinical and prognostic data were analyzed in this study. The diagnosis of these GBC samples was verified by two different pathologists (H.X. and H.B.T.) who were blinded to the clinical follow-up data. The tumor differentiation was graded (G1-3) according to World Health Organization standards, and cancer staging was performed using the 7th edition of TNM staging for GBC issued by the American Joint Committee on Cancer (AJCC). Curative resection (R0 resection) was defined as no residual tumor status, whereas microscopic (R1 resection) and macroscopic residual tumor ( $\mathrm{R} 2$ resection) were defined as non-curative resection. The group comprised 27 men and 44 women with a mean age of $66 \pm 13$ years (mean $\pm \mathrm{SD}$, range $36-92$ years). $\mathrm{R} 0$ and $\mathrm{R} 1,2$ for GBC patients were observed in 39 of $71(54.9 \%)$ and 32 of 71 (45.1\%), respectively. Follow-up data were recorded from the patient's medical records and completed by a telephone survey, routine visit record and address. Clinical outcome was followed from the date of surgery to the date of death or until the end of June 30, 2011. Cases lost during follow-up were regarded as censored data for the survival analysis. Overall survival (OS) was defined as the time (months) from the day of surgery until death of any cause. The median follow-up period for all patients was 17 (range, 2-60) months. The overall 5-year survival rate was $12.7 \%$ (9/71). Clinical and histopathological data are summarized in Table I.

$H \& E$ staining and CD31-PAS double staining. Seventy-one sections $(4 \mu \mathrm{m})$ were cut from archival formalin-fixed paraffinembedded tissue blocks. The samples were deparaffinized and dehydrated using a graded series of ethanol solutions and stained with hematoxylin-eosin (H\&E). Companion serial sections were stained with double staining of CD31 and PAS. They were air-dried, endogenous peroxide activity was blocked with $3 \%$ hydrogen peroxide in $50 \%$ methanol for $10 \mathrm{~min}$ at room temperature, The slides were washed in phosphate-buffered saline (PBS, $\mathrm{pH}$ 7.4), then pretreated with $0.01 \mathrm{M}$ citrate buffer ( $\mathrm{pH}$ 6.0) for twice $5 \mathrm{~min}$ each time at $100^{\circ} \mathrm{C}$ in a microwave oven, then the slides were allowed to cool at room temperature and washed in PBS again, the sections were incubated with mouse monoclonal anti-CD31 protein IgG (MS-1873-SO, dilution:1:50, Neomarkers, Fremont, CA, USA) at $4^{\circ} \mathrm{C}$ overnight, after being rinsed with PBS again, the sections were incubated with goat anti-mouse Envision kit (GK400105, Genetech, USA) for $30 \mathrm{~min}$ at $37^{\circ} \mathrm{C}$ followed by incubation with 3,3-diaminobenzidine (DAB) chromogen for $5 \mathrm{~min}$ at room temperature and washing distilled water, then the section were incubated with $0.5 \%$ periodic acid and Schiff solutions (PAS) for $10 \mathrm{~min}$ in a dark chamber and washing with distilled water for $3 \mathrm{~min}$. Finally all of these sections were counterstained with hematoxylin.

Definition of VM and microvessel density (MVD). VM was first identified with $H \& E$ staining and then validated with CD31-PAS double staining. In H\&E stained slides, VM was defined as the presence of channels that were surrounded by tumor cells in which red blood cells (RBCs) were variably present. In addition, in CD31-PAS double-stained slides, VM was determined as PAS-positive channels lined by tumor cells exclusively, not endothelial cells including RBCs. Microvessel was determined by light microscopy examination of CD31stained sections at the site with the greatest number of capillaries and small venules. The average vessel count of five fields (x400) with the greatest neovascularization was regared as the microvessel density (MVD).

HIF-1a immunohistochemical staining. The immunohistochemical method was performed as previously described (33). Briefly, after deparaffinizing, inactivating endogenous peroxide activity, the samples were washed in PBS, then pretreated with $0.01 \mathrm{M}$ citrate buffer $(\mathrm{pH} \mathrm{6.0)}$ for $30 \mathrm{~min}$ at $100^{\circ} \mathrm{C}$ in a boiler, then the slides were allowed to cool at room temperature and washed in PBS again. Slides were then incubated with the primary antibodies to HIF-1 $\alpha$ (mouse monoclonal, MS-1164-PO, dilution 1:100, Neomarkers) at $4^{\circ} \mathrm{C}$ overnight. Then by a brief rinse in PBS, the sections were incubated with goat anti-mouse Envision kit (GK400105, Genetech, USA) for $30 \mathrm{~min}$ at $37^{\circ} \mathrm{C}$, DAB for $5 \mathrm{~min}$ and counterstained by hematoxylin. Negative controls were established by replacing the primary antibody with PBS in all samples, known immunoassaying-positive colorectal carcinoma sections were used as positive controls.

Evaluation of immunohistochemistry. The positive expression of HIF-1 $\alpha$ was in the nuclear and /or cytoplasm of cancer cells. HIF-1 $\alpha$ was scored with IHC using a semi-quantitative system as previously described (34). Each section was assigned a score and the score of tumor cell staining was multiplied by the score of staining intensity. Tumor cell staining was scored using a semi-quantitative six-category grading system: 0 , no tumor cell staining; $1,1-10 \%$ of tumor cells staining; 2 , $11-25 \%$ of tumor cells staining; $3,26-50 \%$ of tumor cells staining; $4,51-75 \%$ of tumor cells staining; 5 , over $75 \%$ of tumor cells staining. Stain intensity was scored using a semiquantitative four category grading system: 0 , no staining; 1 , weak staining; 2 , moderate staining; 3 , strong staining. Two experienced pathologists blinded to the clinical follow-up data independently scored the 71 GBC samples including the cases used in this study. The complete score agreement of the two pathologists (H.X. and H.B.T.) was 87.3\% (62/71) of all cases, 
Table I. Correlation between VM and clinicopathological factors in patients with gallbladder carcinoma.

\begin{tabular}{|c|c|c|c|c|c|}
\hline \multirow[b]{2}{*}{ Variables } & \multirow[b]{2}{*}{$\mathrm{n}$} & \multicolumn{2}{|c|}{ Vasculogenic mimicry } & \multirow[b]{2}{*}{$\chi^{2}$-value } & \multirow[b]{2}{*}{ P-value } \\
\hline & & Negative $(\%)$ & Positive (\%) & & \\
\hline Patients & 71 & 53 & 18 & & \\
\hline \multicolumn{6}{|l|}{ Gender } \\
\hline Male & 27 & $18(66.7)$ & $9(33.3)$ & 1.4665 & 0.2259 \\
\hline Female & 44 & $35(79.5)$ & $9(20.5)$ & & \\
\hline \multicolumn{6}{|l|}{ Age (years) } \\
\hline$\leq 66$ & 33 & $24(72.7)$ & $9(27.3)$ & 0.1202 & 0.7288 \\
\hline$>66$ & 38 & $29(76.3)$ & $9(23.7)$ & & \\
\hline \multicolumn{6}{|l|}{ Tumor location } \\
\hline Bottom & 37 & $25(67.6)$ & $12(32.4)$ & 2.0467 & 0.1525 \\
\hline Corporis and others & 34 & $28(82.4)$ & $6(17.6)$ & & \\
\hline \multicolumn{6}{|l|}{ Tumor size $(\mathrm{cm})$} \\
\hline$\leq 3$ & 41 & $33(80.5)$ & $8(19.5)$ & 1.7486 & 0.1860 \\
\hline$>3$ & 30 & $20(66.7)$ & $10(33.3)$ & & \\
\hline \multicolumn{6}{|l|}{ Histological type } \\
\hline Adenocarcinoma & 63 & $50(79.4)$ & $13(20.6)$ & 5.6672 & $0.0173^{\mathrm{a}}$ \\
\hline Others $^{b}$ & 8 & $3(37.5)$ & $5(62.5)$ & & \\
\hline \multicolumn{6}{|c|}{ Histological differentiation } \\
\hline $\mathrm{G}_{1}$ (high) & 11 & $7(63.6)$ & $4(36.4)$ & 0.8441 & 0.6557 \\
\hline $\mathrm{G}_{2}$ (moderate) & 25 & $19(76.0)$ & $6(24.0)$ & & \\
\hline $\mathrm{G}_{3}($ poor $)$ & 35 & $27(77.1)$ & $8(22.9)$ & & \\
\hline \multicolumn{6}{|l|}{ Depth of invasion } \\
\hline Tis, $\mathrm{T}_{1}, \mathrm{~T}_{2}$ & 28 & $22(78.6)$ & $6(21.4)$ & 0.3761 & 0.5397 \\
\hline $\mathrm{T}_{3}, \mathrm{~T}_{4}$ & 43 & $31(72.1)$ & $12(27.9)$ & & \\
\hline \multicolumn{6}{|l|}{ Venous invasion } \\
\hline Negative & 42 & $32(76.2)$ & $10(23.8)$ & 0.1293 & 0.7192 \\
\hline Positive & 29 & $21(70.0)$ & $8(30.0)$ & & \\
\hline \multicolumn{6}{|l|}{ Lymph node metastasis } \\
\hline Negative & 39 & $30(76.9)$ & $9(23.1)$ & 0.2367 & 0.6266 \\
\hline Positive & 32 & $23(71.9)$ & $9(28.1)$ & & \\
\hline \multicolumn{6}{|l|}{ Liver infiltration } \\
\hline Negative & 38 & $32(84.2)$ & $6(15.8)$ & 3.9505 & $0.0469^{\mathrm{a}}$ \\
\hline Positive & 33 & $21(63.6)$ & $12(36.4)$ & & \\
\hline \multicolumn{6}{|l|}{ Perineural involvement } \\
\hline Negative & 49 & $39(79.6)$ & $10(20.4)$ & 2.0424 & 0.1530 \\
\hline Positive & 22 & $14(63.6)$ & $8(36.4)$ & & \\
\hline \multicolumn{6}{|l|}{ Resection type } \\
\hline R0 & 39 & $32(82.1)$ & $7(17.9)$ & 2.5061 & 0.1134 \\
\hline $\mathrm{R} 1$ or $\mathrm{R} 2$ & 32 & $21(65.6)$ & $11(34.4)$ & & \\
\hline \multicolumn{6}{|c|}{ UICC staging (7th, 2010) } \\
\hline I & 12 & $9(75.0)$ & $3(25.0)$ & 1.0805 & 0.7818 \\
\hline II & 14 & $9(64.3)$ & $5(35.7)$ & & \\
\hline III & 24 & $19(79.2)$ & $5(20.8)$ & & \\
\hline IV & 21 & $16(76.2)$ & $5(23.8)$ & & \\
\hline
\end{tabular}

${ }^{\mathrm{a}} \mathrm{P}<0.05$, statistically significant; VM, vasculogenic mimicry; ${ }^{\mathrm{b}}$ others, mucinous adenocarcinoma, squamous and adenosquamous carcinoma. 

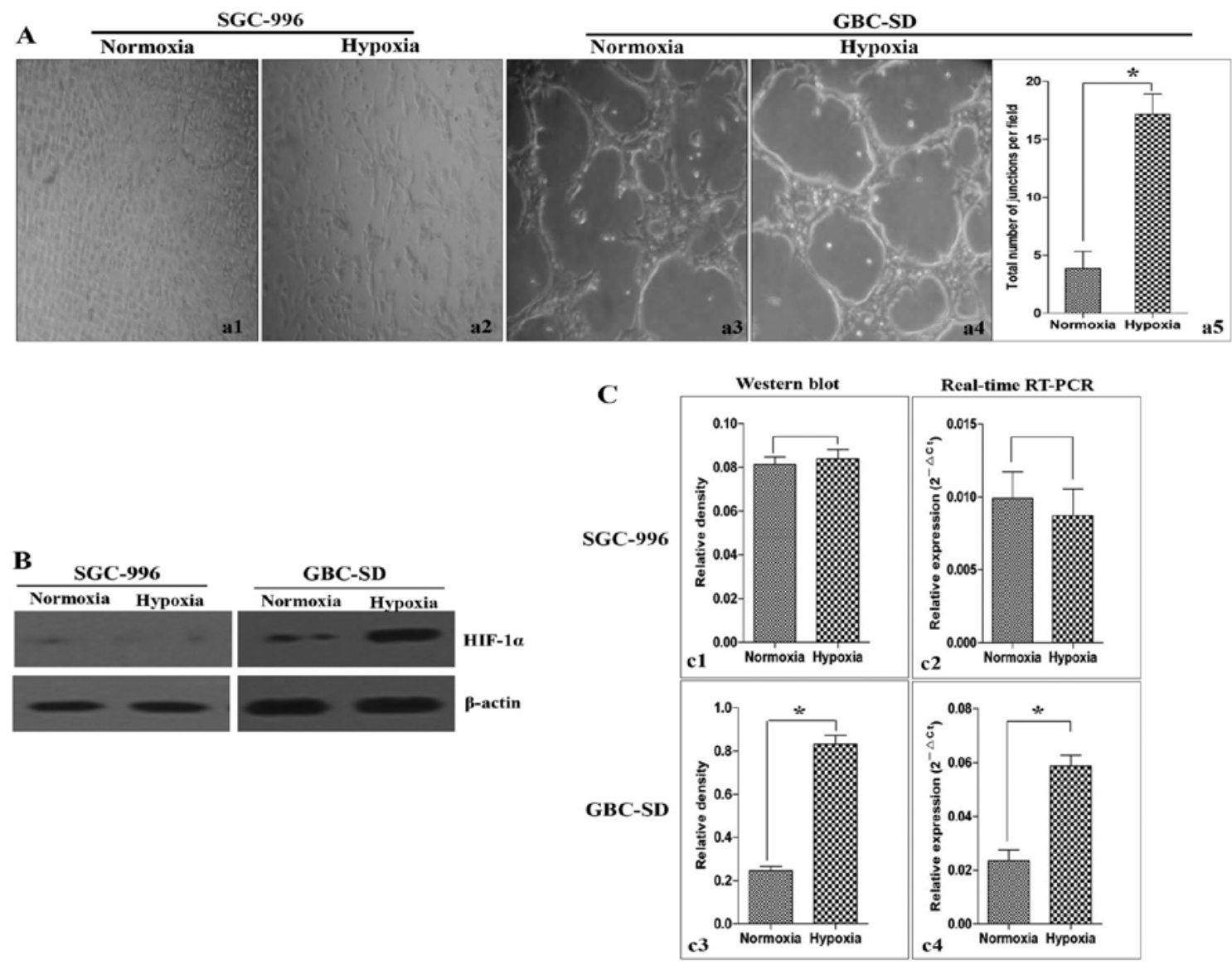

Figure 1. Hypoxia induced VM in gallbladder carcinoma cell lines. (A) GBC-SD cell lines can form typical pipe-like VM networks on Matrigel either under normoxic or hypoxic conditions. Importantly, hypoxia-pretreated GBC-SD cells can form more VM channels compared with unpretreated cells ("P $<0.01$ ). However, SGC-996 cell lines cannot form the same structures either under normoxic or hypoxic conditions on Matrigel. (B and C) The HIF-1 $\alpha$ expression was enhanced in hypoxia-pretreated GBC-SD cells compared to that in GBC-SD cells without hypoxia-pretreatment on protein $($ (P<0.01) and mRNA levels $\left({ }^{*} \mathrm{P}<0.01\right)$. On the contrary, the HIF-1 $\alpha$ expression in SGC-996 cells showed no significant difference between hypoxic conditions and normoxic conditions.

indicating that the scoring method is reasonably reproducible. A third blinded pathologist intervened and evaluated the patients with different IHC scores. If the third pathologist agreed with one of the previous scores, it was used for analysis. The three pathologists were asked to reach an agreement on the cases from which three different scores were obtained.

Selection of cut-off scores. Cut-off scores for MVD and HIF-1 $\alpha$ expression were selected based on receiver operating characteristic (ROC) curve analysis (35). ROC curve was plotted for the outcome of GBC patients under study by calculating the sensitivity and specificity on its points. The score closest to the points $(0.0,1.0)$ on the curve with a maximum sensitivity and specificity was selected as the cut-off score leading to the greatest number of tumors classified with or without clinical outcome. The area under the ROC curve was calculated respectively to estimate the discriminatory power of HIF-1 $\alpha$ protein over the entire range of scores for overall survival (OS) rate of GBC patients. The ROC curve was generated and analyzed using the MedCalc statistical software package 11.0.1 (MedCalc Software bvba, Belgium).

Statistical analysis. SAS 9.1 software (SAS Institute Inc., Cary, NC, USA) was used for statistical analysis. Continuous variables were expressed as mean $\pm \mathrm{SD}$, and analyzed using the two-tailed Student's t-test or two-way ANOVA. Association between VM, HIF-1 $\alpha$ expression and categorical variables was analyzed by Fisher's exact or $\chi^{2}$ test. In addition, correlation of MVD and HIF-1 $\alpha$ expression with VM was analyzed by Spearmen correlation analysis. Survival curves were calculated with the Kaplan-Meier method and were compared using the log-rank test. Multivariate analysis of prognostic factors was performed using the Cox's regression model. $\mathrm{P}<0.05$ was considered statistically significant.

\section{Results}

Hypoxia induces more VM channel formation and elevates $H I F-1 \alpha$ expression in GBC-SD cells. To address to the role of hypoxia during VM channel formation, highly aggressive cell lines (GBC-SD) and poorly aggressive cell lines (SGC-996) were either not pretreated (normoxic condition) or pretreated with chronic hypoxia $\left(2 \% \mathrm{O}_{2}, 2 \% \mathrm{CO}_{2}\right.$ and $\left.96 \% \mathrm{~N}_{2}, 48 \mathrm{~h}\right)$ and cultured on a three-dimensional matrix for 2 days. As shown in Fig. 1A, GBC-SD cell lines exhibited a chord-like phenotype with the formation of an interlacing arborizing pattern on Matrigel either under normoxic or hypoxic conditions. In contrast, SGC-996 cell lines failed to form the same structures 

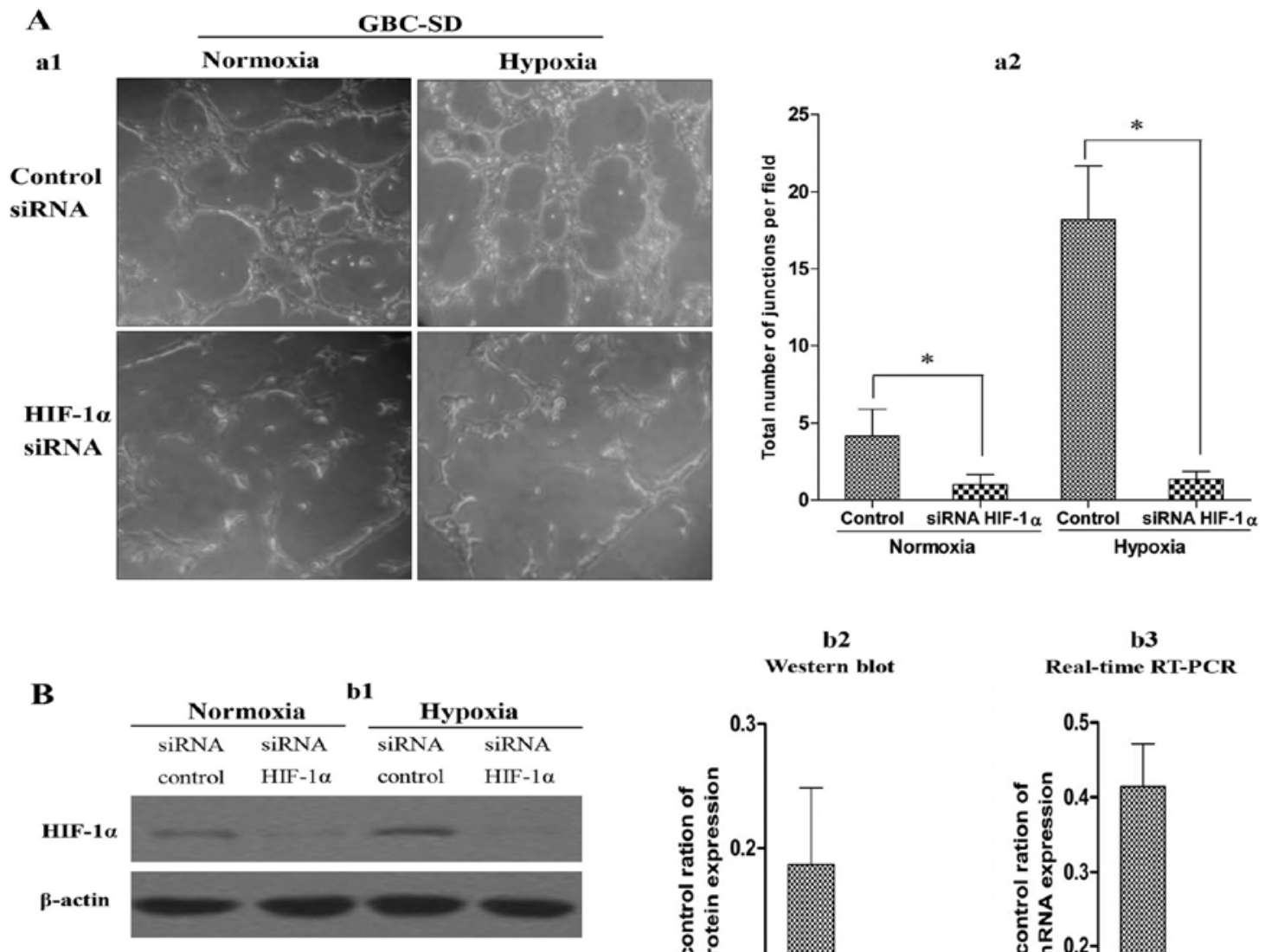

b2

Western blot

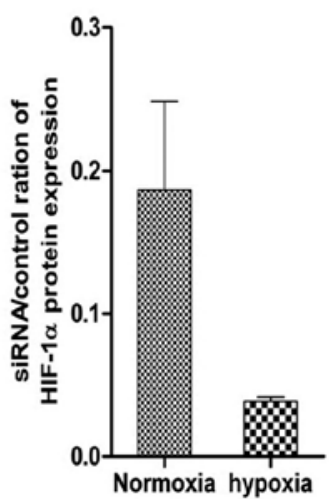

b3

Real-time RT-PCR

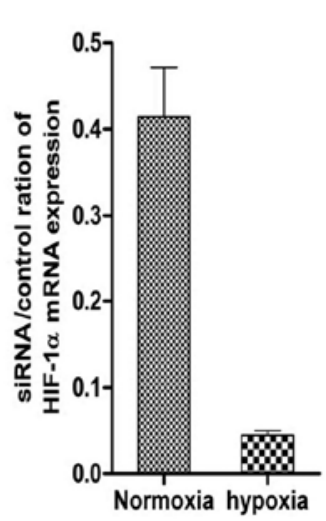

Figure 2. Small interfering RNA (siRNA) against HIF-1 $\alpha$ inhibited VM channel formation and HIF-1 $\alpha$ expression of GBC-SD cells in three-dimensional Matrigel culture. (A) HIF-1 $\alpha$ siRNA blocked the VM channel formation of GBC-SD cells in three-dimensional Matrigel culture under either normoxic $($ ( $\mathrm{P}<0.01)$ or hypoxic conditions ("P<0.01), whereas the control siRNA showed no inhibition effect on VM networks. (B) The HIF-1 $\alpha$ protein or mRNA expression with HIF-1 $\alpha$ siRNA was reduced more significantly than that with control siRNA under hypoxic conditions and normoxic conditions, respectively.

either under normoxic or hypoxic conditions on Matrigel. Furthermore, exposure to hypoxia was able to strongly increase the VM of GBC-SD cells, assayed as their ability to self-organize into vascular-like networks onto Matrigel surfaces $(\mathrm{t}=14.41, \mathrm{P}=0.0001)$. In addition, western blot analysis showed that HIF-1 $\alpha$ protein in GBC-SD cell lines was highly expressed under hypoxic conditions compared to that under normoxic conditions ( $\mathrm{t}=22.66, \mathrm{P}=0.0004)$ (Fig. 1B and $\mathrm{Cc} 3$ ). Real-time RT-PCR was carried out to determine whether the level of HIF-1 $\alpha$ protein was also apparent at mRNA level. In parallel with upregulation of HIF-1 $\alpha$ protein in GBC-SD cell lines under normoxic conditions, which were found to show significantly higher levels of HIF- $1 \alpha$ mRNA in comparison with that under hypoxic conditions $(\mathrm{t}=10.66, \mathrm{P}=0.0004)$ (Fig. 1B and Cc4). On the contrary, the HIF-1 $\alpha$ expression in SGC-996 cells showed no significant difference between hypoxic conditions and normoxic conditions on protein $(\mathrm{t}=0.84, \mathrm{P}=0.4502)$ and mRNA levels $(\mathrm{t}=0.82, \mathrm{P}=0.4593)$ (Fig. 1B and $\mathrm{Cc1}$ and 2).

Small interfering RNA against HIF-1 $\alpha$ inhibits VM channel formation and HIF-1 $\alpha$ expression in GBC-SD cells. To further assess the possible correlation between HIF-1 $\alpha$ expression and VM channel formation under hypoxic conditions and normoxic conditions in highly aggressive GBC-SD cell lines, the effects of special HIF-1 $\alpha$ siRNA on VM formation were evaluated. As shown in Fig. 2A, the results indicated that HIF- $1 \alpha$-siRNA significantly suppressed the VM networks under either normoxic $(\mathrm{t}=4.23, \mathrm{P}=0.0049)$ or hypoxic conditions ( $\mathrm{t}=11.68, \mathrm{P}=0.0001)$, whereas the control siRNA showed no inhibited effect on VM networks. It is of note that the HIF-1 $\alpha$ protein or mRNA expression with HIF- $1 \alpha$ siRNA was reduced more dramatically than that with control siRNA under hypoxic conditions and normoxic conditions, respectively (Fig. 2B), suggesting HIF-1 $\alpha$ siRNA efficiently knocked down HIF-1 $\alpha$ expression.

Evidence of VM in GBC tissue samples. As shown in Fig. 3A, VM was observed in 18 of 71 (25.4\%) GBC samples using $\mathrm{H} \& \mathrm{E}$ staining and dual-staining with CD31-PAS under a light microscope. Morphometrically the red blood cells were surrounded by channels with tumor cell lining, not by endothelial cells. Many PAS-positive loops forming networks and CD31-positive endothelial cells were seen in the sections, the 

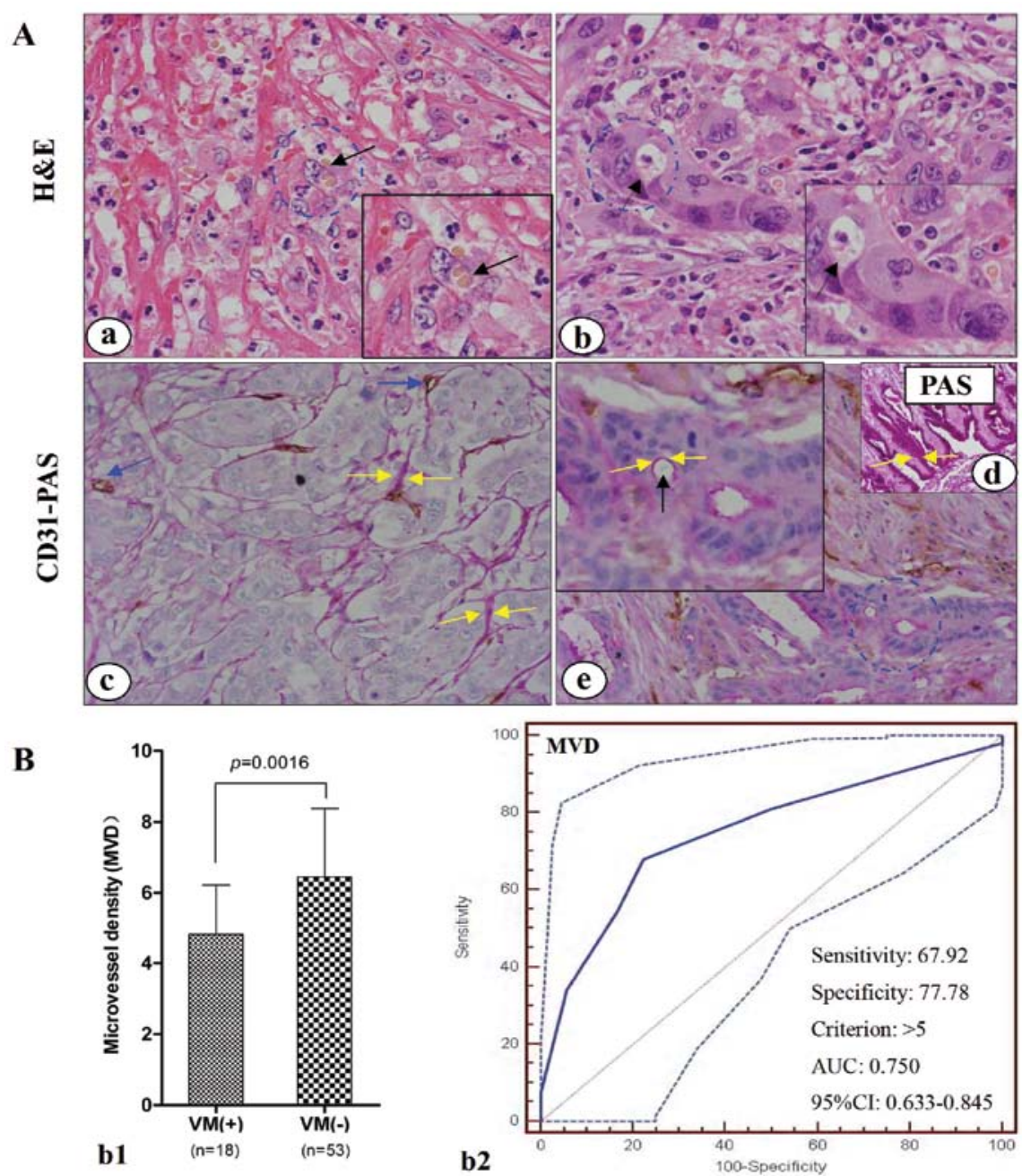

Figure 3. Evidence of vasculogenic mimicry (VM) and relationship between VM and MVD in human gallbladder carcinoma (GBC). (A) Morphological appearance of VM (Envision, original magnification, $\mathrm{x} 400$ ) with HE staining (a and b), periodic acid-Schiff (PAS) staining for normal gastric mucosa (d) and CD31- PAS double staining ( $\mathrm{c}$ and e). The VM channel (black arrow) was lined only by tumor cells, single or several red blood cells (RBCs) therein (a and b). Normal gastric mucosa (d) and GBC samples (c and e) exhibited PAS-positive staining (cherry-red, yellow arrow), respectively. The endothelial cells lining the vessel were positive (blue arrow) for CD31 (c); The presence of CD31-PAS double staining of VM (black arrow), the wall of VM channel was positive for PAS staining, while tumor cells lining the external wall were negative for CD31 staining; CD31-negative tumor cell lining of vascular structures contained RBCs (e, black arrow). (B) The GBC patients with VM-negative group had a higher MVD than that in the VM-positive group (b1, $\mathrm{P}=0.0016$ ). ROC analysis of MVD in gallbladder carcinoma, the threshold value of 5 was the optimal point for maximum sensitivity and specificity, and selected as cut-off score (b2).

histological presence of closed loops of PAS-positive materials encircled small clusters of tumor cells. The CD31-PAS dual staining sections were viewed to further investigate the evidence of VM in GBC samples. The channels defined as VM were lined by PAS-positive material with red cells in the center of the channels, but not lined by CD31-positive endothelial cells. Hence, the $71 \mathrm{GBC}$ samples were categorized into VM-positive $(n=18)$ and VM-negative ( $n=53)$ groups.

Relationship between VM and MVD. To elucidate the relationship between VM and MVD, the MVD between the VM-positive group $(n=18)$ and VM-negative group $(n=53)$ in 71 patients with GBC was compared. A higher MVD was observed in VM-negative group than in VM-positive group (6.4528 \pm 1.9272 vs. $4.8333 \pm 1.3827, \mathrm{t}=3.28, \mathrm{P}=0.0016$; Fig. 3Bb1). According to the ROC curves for MVD (Fig. 3Bb2), a threshold value of 5 was the optimal point for maximum sensitivity and specificity, and selected as cut-off score. The
AUC of our ROC curve analysis was 0.75 [95\% confidence interval (CI): 0.633-0.845], correlation analysis revealed a negative correlation between VM and MVD ( $r=-0.30592$, $\mathrm{P}=0.0095)$.

Correlation between VM and clinicopathological features. As shown in Table I, VM was not correlated with gender, age, location and diameter of carcinoma, differentiation degree, venous invasion, lymph node metastasis, perineural involvement, depth of invasion and UICC staging. However, VM was closely associated with histological type $\left(\chi^{2}=5.6672, \mathrm{P}=0.0173\right)$, and liver infiltration $\left(\chi^{2}=3.9505, \mathrm{P}=0.0469\right)$. Additionally, there were no differences between VM-positive group and VM-negative group among squamous carcinoma, mucinous adenocarcinoma and squamous carcinoma histological types.

Association between HIF-1 $\alpha$ expression and clinicopathological features in GBC patients with VM and non-VM. We 


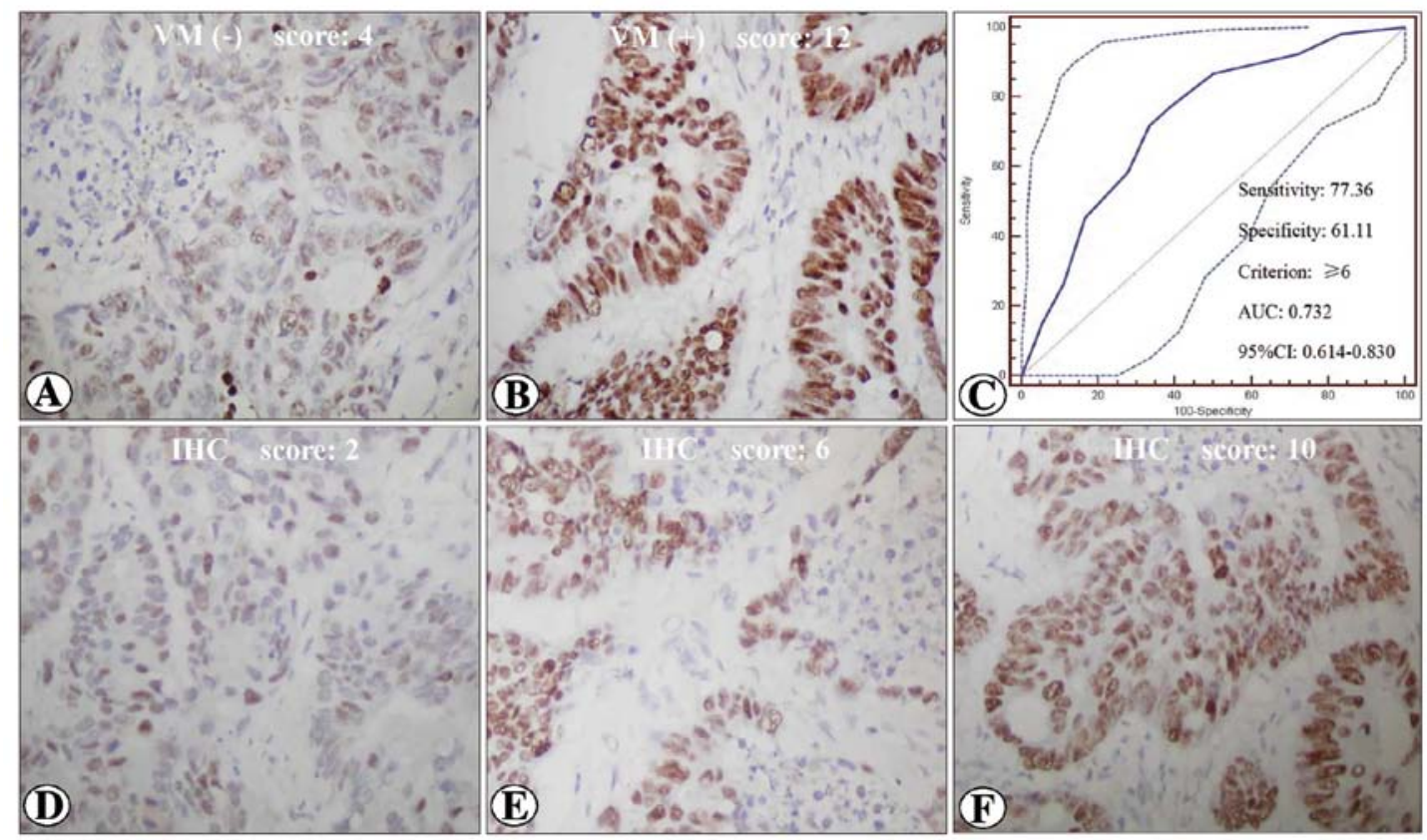

Figure 4. Expression of HIF-1 $\alpha$ protein in GBC samples with VM and non-VM by immunohistochemistry (Envision, original magnification, $\mathrm{x} 400$ ). HIF-1 $\alpha$ expression showed mixed nuclear and cytoplasmic staining; representative staining of HIF-1 $\alpha$ in GBC samples with VM-negative (A) and VM-positive (B). ROC analysis of HIF-1 $\alpha$ protein expression and selection of cut-off score (C). (D) HIF-1 $\alpha$ detection immunoreactive sore (IRS) 2; (E) HIF-1 $\alpha$ detection IRS 6; (F) HIF-1 $\alpha$ detection IRS 10.

Table II. Relationship between HIF-1 $\alpha$ expression and clinicopathological parameters in GBC with VM and non-VM group.

\begin{tabular}{|c|c|c|c|c|c|c|}
\hline \multirow[b]{2}{*}{ Variables } & \multicolumn{3}{|c|}{ HIF-1 $\alpha$ expression in $\mathrm{VM}(+)$ group } & \multicolumn{3}{|c|}{ HIF-1 $\alpha$ expression in $\mathrm{VM}(-)$ group } \\
\hline & Low $(n=7)$ & High $(n=11)$ & P-value & Low $(n=41)$ & $\operatorname{High}(\mathrm{n}=12)$ & P-value \\
\hline Age (years) & $63 \pm 9$ & $68 \pm 8$ & NS & $65 \pm 11$ & $65 \pm 7$ & NS \\
\hline Gender (male/female) & $5 / 2$ & $4 / 7$ & NS & $14 / 27$ & $4 / 8$ & NS \\
\hline Tumor location bottom/corporis and others & $4 / 3$ & $8 / 3$ & NS & $19 / 22$ & $6 / 6$ & NS \\
\hline Tumor size $(\mathrm{cm})$ & $3.1 \pm 1.7$ & $3.6 \pm 1.5$ & NS & $2.5 \pm 1.5$ & $3.3 \pm 1.6$ & NS \\
\hline Histological type (adenocarcinoma/others ${ }^{b}$ ) & $6 / 1$ & $7 / 4$ & NS & $39 / 2$ & $11 / 1$ & NS \\
\hline Histological differentiation (G1/G2/G3) & $1 / 3 / 3$ & $3 / 3 / 5$ & NS & $6 / 17 / 18$ & $1 / 2 / 9$ & NS \\
\hline Depth of invasion (Tis, $\mathrm{T}_{1}, \mathrm{~T}_{2} / \mathrm{T}_{3}, \mathrm{~T}_{4}$ ) & $3 / 4$ & $3 / 8$ & NS & $21 / 20$ & $1 / 11$ & $0.0204^{\mathrm{a}}$ \\
\hline Venous invasion $((-) /(+))$ & $5 / 2$ & $5 / 6$ & NS & $27 / 14$ & $5 / 7$ & NS \\
\hline Lymph node metastasis $(-) /(+)$ & $5 / 2$ & $4 / 7$ & NS & $24 / 17$ & $6 / 6$ & NS \\
\hline Liver infiltration $(-) /(+)$ & $3 / 4$ & $3 / 8$ & NS & $27 / 14$ & $5 / 7$ & NS \\
\hline Perineural involvement $(-) /(+)$ & $4 / 3$ & $6 / 5$ & NS & $34 / 7$ & $5 / 7$ & $0.0132^{\mathrm{a}}$ \\
\hline Resection type (R0/R1,2) & $4 / 3$ & $3 / 8$ & NS & $27 / 14$ & $5 / 7$ & NS \\
\hline UICC staging (7th, 2010) (I/II/III/IV) & $2 / 2 / 2 / 1$ & $1 / 3 / 3 / 4$ & NS & $9 / 8 / 12 / 12$ & $0 / 1 / 7 / 4$ & NS \\
\hline
\end{tabular}

${ }^{\mathrm{a}} \mathrm{P}<0.05$, statistically significant; $\mathrm{VM}$, vasculogenic mimicry; ${ }^{\mathrm{b}}$ others, mucinous adenocarcinoma, squamous and adenosquamous carcinoma; GBC, gallbladder carcinoma; HIF-1, hypoxia-inducible factor-1; NS, not significant.

further analyzed the relationship between HIF-1 $\alpha$ expression and clinicopathological data in GBC with VM and non-VM by immunohistochemistry. According to the ROC curve in our study, a threshold value of 6 was the closest to the point with both maximum sensitivity and specificity, and thereby selected as the cut-off score. The AUC of our ROC curve analysis was 0.732 (95\% CI, 0.614-0.830). Therefore, the 71 GBC specimens were categorized into high and low HIF-1 $\alpha$ expression groups (Fig. 4). The expression level of HIF-1 $\alpha$ was upregulated in $11(61.1 \%)$ and downregulated in $7(38.9 \%)$ cases in VM group, and upregulated in $12(22.6 \%)$ and downregulated in $41(77.4 \%)$ cases in non-VM group. As shown in Table II, no significant correlations were observed between HIF-1 $\alpha$ expression and any clinicopathological variables in VM group. 
Table III. Univariate and multivariate analysis of overall survival rate of GBC patients with Cox proportional hazards model.

\begin{tabular}{|c|c|c|c|c|c|c|}
\hline \multirow[b]{2}{*}{ Variables } & \multicolumn{3}{|c|}{ Univariate analysis } & \multicolumn{3}{|c|}{ Multivariate analysis } \\
\hline & HR & $95 \% \mathrm{CI}$ & $\mathrm{P}$-value & HR & $95 \% \mathrm{CI}$ & P-value \\
\hline \multicolumn{7}{|l|}{ Gender } \\
\hline Male vs. female & 0.809 & $0.397-1.648$ & 0.5592 & & & \\
\hline \multicolumn{7}{|l|}{ Age (years) } \\
\hline$\leq 63$ vs. $>63$ & 0.822 & $0.445-1.519$ & 0.5313 & & & \\
\hline \multicolumn{7}{|l|}{ Tumor location } \\
\hline Bottom vs. corporis and others & 0.829 & $0.447-1.535$ & 0.5501 & & & \\
\hline \multicolumn{7}{|l|}{ Tumor size $(\mathrm{cm})$} \\
\hline$\leq 3$ vs. $>3$ & 0.716 & $0.365-1.401$ & 0.3292 & & & \\
\hline \multicolumn{7}{|l|}{ Histological type } \\
\hline Adenocarcinoma vs. others ${ }^{\mathrm{a}}$ & 1.114 & $0.427-2.901$ & 0.8257 & & & \\
\hline \multicolumn{7}{|l|}{ Histological differentiation } \\
\hline G1 vs. G2 and G3 & 1.989 & $1.165-3.395$ & $0.0117^{\mathrm{b}}$ & 1.992 & $1.231-3.225$ & $0.005^{\mathrm{c}}$ \\
\hline \multicolumn{7}{|l|}{ Depth of invasion } \\
\hline Tis $, T_{1}, T_{2}$ vs. $T_{3}, T_{4}$ & 15.885 & $3.004-84.008$ & $0.0011^{\mathrm{c}}$ & 6.926 & $2.005-23.932$ & $0.0022^{\mathrm{c}}$ \\
\hline \multicolumn{7}{|l|}{ Venous invasion } \\
\hline Negative vs. positive & 0.549 & $0.234-1.284$ & 0.1664 & & & \\
\hline \multicolumn{7}{|l|}{ Lymph node metastasis } \\
\hline Negative vs. positive & 14.727 & $3.384-64.081$ & $0.0003^{c}$ & 14.972 & $3.791-59.125$ & $0.0001^{\mathrm{c}}$ \\
\hline \multicolumn{7}{|l|}{ Liver infiltration } \\
\hline Negative vs. positive & 0.451 & $0.103-1.972$ & 0.2899 & & & \\
\hline \multicolumn{7}{|l|}{ Perineural involvement } \\
\hline Negative vs. positive & 1.690 & $0.804-3.550$ & 0.1660 & & & \\
\hline \multicolumn{7}{|l|}{ Resection type } \\
\hline R 0 vs. R1,2 & 9.379 & $1.833-48.00$ & $0.0072^{\mathrm{c}}$ & 6.144 & $1.812-20.836$ & $0.0036^{\mathrm{c}}$ \\
\hline \multicolumn{7}{|l|}{ UICC staging (7th, 2010) } \\
\hline I/II/III/IV & 3.127 & $1.611-5.886$ & $0.0004^{c}$ & 2.213 & $1.309-3.741$ & $0.003^{c}$ \\
\hline \multicolumn{7}{|l|}{ Vasculogenic mimicry } \\
\hline Negative vs. positive & 2.676 & $1.040-6.881$ & $0.0411^{\mathrm{b}}$ & 2.567 & $1.330-4.956$ & $0.005^{\mathrm{c}}$ \\
\hline \multicolumn{7}{|l|}{ HIF- $1 \alpha$ expression } \\
\hline Low vs. high & 2.129 & $1.051-4.314$ & $0.0359^{\mathrm{b}}$ & 2.251 & $1.152-4.398$ & $0.0176^{\mathrm{b}}$ \\
\hline
\end{tabular}

${ }^{\mathrm{a}}$ Others, mucinous adenocarcinoma, squamous and adenosquamous carcinoma; ${ }^{\mathrm{b}} \mathrm{P}<0.05,{ }^{\mathrm{c}} \mathrm{P}<0.01$, statistically significant; GBC, gallbladder carcinoma; CI, confidence interval; HR, hazard ratio; HIF-1 $\alpha$, hypoxia-inducible factor-1 $\alpha$.

However, increased HIF-1 $\alpha$ expression in GBC specimens was significantly correlated with depth of invasion $(\mathrm{P}=0.0204)$ and perineural involvement $(\mathrm{P}=0.0132)$ in non-VM group. In addition, Spearman rank correlation test showed that VM had positive correlation with HIF-1 $\alpha$ expression in GBC samples $(\mathrm{r}=0.3576, \mathrm{P}=0.0022)$.

Univariate and multivariate survival analysis. Factors involved in overall survival (OS) rate of GBC patients were identified using the Cox proportional hazards model (Table III). Univariate analysis showed that histological differentiation $(\mathrm{P}=0.0117)$, depth of invasion $(\mathrm{P}=0.0011)$, lymph node metastasis $(\mathrm{P}=0.0003)$, resection type $(\mathrm{P}=0.0072), \mathrm{UICC}$ staging $(\mathrm{P}=0.0004), \mathrm{VM}(\mathrm{P}=0.0411)$ and $\mathrm{HIF}-1 \alpha$ expression $(\mathrm{P}=0.0359)$ were significant prognostic indicators for the OS rate of GBC patients. Cox proportional regression analysis was carried out to determine which factor was the best prognostic determinant. All factors tested on univariate analysis were included in the same Cox regression model. Further multivariate analysis confirmed histological differentiation (hazard risk=1.992, 95\% CI: 1.231-3.225, $\mathrm{P}=0.005)$, depth of invasion (hazard risk=6.926, 95\% CI: 2.005-23.932, $\mathrm{P}=0.0022$ ), lymph node metastasis (hazard risk=14.972, 95\% CI: 3.791-59.125, $\mathrm{P}=0.0001$ ), resection type (hazard risk $=6.144$, 95\% CI: 1.812 20.836, $\mathrm{P}=0.0036$ ), UICC staging (hazard risk $=2.213,95 \% \mathrm{CI}$ : $1.309-3.741, \mathrm{P}=0.003), \mathrm{VM}$ (hazard risk $=2.567,95 \% \mathrm{CI}: 1.330$ - 
A
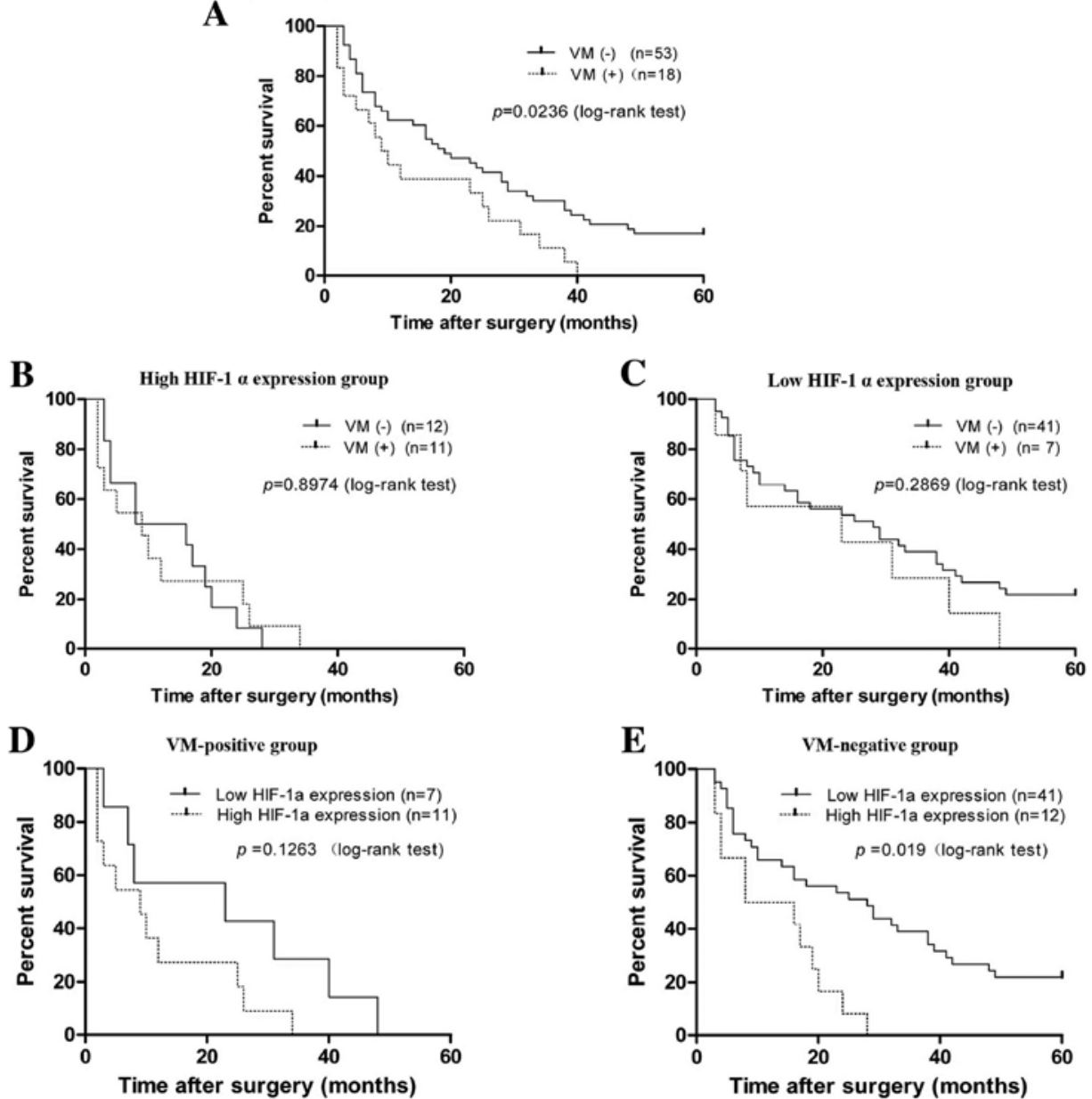

Figure 5. Kaplan-Meier survival curves for patients with gallbladder carcinoma according to VM (A) and HIF-1 $\alpha$ expression (B-E). These Kaplan-Meier curves demonstrate significantly worse outcomes for patients with (A) vasculogenic mimicry and (E) high HIF-1 $\alpha$ expression in VM-negative group.

4.956, $\mathrm{P}=0.005$ ) and HIF-1 $\alpha$ expression (hazard risk=2.251, 95\% CI: $1.152-4.398, \mathrm{P}=0.0176$ ) were the independent prognostic factors for the OS rate of GBC patients.

Kaplan-Meier analysis and the log-rank test were used to further evaluate the VM and HIF-1 $\alpha$ expression status on 5-year survival rate of $71 \mathrm{GBC}$ patients. The medians for survival time of the VM group were 9.5 months, compared with 19 months for non-VM group. The cumulative 1-, 3- and 5 -year OS rate were 44.4, 11.1 and $0 \%$ in the VM group and $62.3,30.2$ and $17.0 \%$ in the non-VM group, respectively. The survival time of the VM group were significantly shorter than that of the non-VM group with a Kaplan-Meier analysis (Fig. 5A, $\mathrm{P}=0.0236$ ). In addition, patients with low HIF-1 $\alpha$ expression had a better survival than those with high HIF-1 $\alpha$ expression (Fig. 5E, $\mathrm{P}=0.019$ ) in the non-VM group. However, as shown in Fig. 5B-D, Kaplan-Meier analysis and the log-rank test failed to demonstrate the significant difference between low HIF-1 $\alpha$ and high expression either in VM or non-VM group, respectively $(\mathrm{P}>0.05)$.

\section{Discussion}

The results presented in the present study lead to these major conclusions: i) hypoxia could induced more VM channels formation and elevated HIF-1 $\alpha$ expression in highly aggres- sive GBC-SD cells; ii) HIF-1 $\alpha$ siRNA efficiently knocked down HIF-1 $\alpha$ expression and GBC VM networks under either normoxic or hypoxic conditions; and iii) VM exists in human primary GBC and overexpression of HIF-1 $\alpha$ was significantly correlated with depth of invasion and perineural involvement in non-VM group. Moreover, VM and HIF-1 $\alpha$ were independent factors for OS of GBC patients and correlated with decreased survival.

Tumor microenvironment significantly underlies tumor cell plasticity $(36,37)$. Hypoxia in the tumor enviroment is sufficient to activate HIF-dependent gene expression (34). We have previously demonstrated that highly aggressive GBC-SD cells could display VM channel formation in three-dimensional Matrigel culture and GBC-SD nude mouse xenografts in vivo. On the contrary, poorly aggressive SGC-996 cells failed to exhibit similar structures in vitro and in vivo (31). In the current study, we firstly compared the ability of highly aggressive GBC-SD cells with that of poorly aggressive SGC-996 cells to display VM channel formation in three-dimensional Matrigel culture under normoxic or hypoxic conditions. Our data showed that GBC-SD cells efficiently formed VM either under normoxic or hypoxic conditions and exhibited more VM structures under hypoxic conditions, whereas SGC-996 cells formed hardly any tubular networks at all, even though under hypoxic conditions, which is in line with previous 
studies in other types of carcinoma $(25,38)$, suggesting that hypoxia could promote tumor cell migration and invasion to form tubular networks in three-dimensional Matrigel culture. Although we failed to undertake Transwell chambers and wound healing methods to evaluate the effect of hypoxia on tumor cell migration and invasion in vitro in the present study, it is still reasonable to speculate that SGC-996 cells could not reach high enough migration and invasion to form VM channels onto Matrigel surfaces under hypoxic conditions.

We next determined whether HIF-1 $\alpha$ would play an important role in VM in GBC-SD cells when cultured in three-dimensional Matrigel. Our data revealed that the highly aggressive GBC-SD cells displayed elevated HIF-1 $\alpha$ expression at protein and mRNA levels under hypoxic conditions compared to that under normoxic conditions. Furthermore, our current findings indicated that the transfection of GBC-SD with HIF-1 $\alpha$ siRNA could significantly knock down the HIF-1 $\alpha$ gene and protein expression, as well as VM channel formation, which is agreement with several published studies $(23,24,28)$, strongly suggesting that HIF-1 $\alpha$ is the crucial mediator of VM. Vartanian et al (26) revealed that the elevated reactive oxygen species (ROS) level or VEGF expression in melanoma was key requirement for capillary-like-structure (CLS) formation. In addition, epithelial cell kinase (EphA2) might be one of the important factors regulated by HIF-1 $\alpha$ in VM formation in esophageal squamous cancer cells in vivo (23). Furthermore, the expression levels of VM-associated genes, including laminin-5 $\gamma^{2}$, EphA2, TF pathway inhibitor-1 (TFPI-1) and Tie-1, were found to be increased significantly under hypoxic conditions in Ewing sarcoma (EW-7 and A673) and melanoma (C8161) cell lines (28). However, to identify the key molecular mechanisms of HIF-1 $\alpha$ that regulated VM formation, further studies are needed.

VM describes the ability of tumor cells to express endothelium-and epithelium-associated genes and form extracellular matrix-rich tubular networks that mimic the pattern of embryonic vasculogenic networks (39). Tumor cell plasticity underlies VM $(8,37)$. Furthermore, VM channels and PAS patterns were associated with poor clinical outcome $(10-12,14,18)$. VM was lined by tumor cells instead of endothelial cells without necrosis, hemorrhage, or inflammatory cells in the environment. Consequently, $\mathrm{H} \& \mathrm{E}$ staining and CD31/CD34-PAS double staining were the major identification methods of VM under light microscope and applied in several tumors $(15,17,40,41)$. In this study, we found that the channels defined as VM were enclosed by GBC cells and lined by PAS-positive material with red cells in the center of the channels. In addition, similar structures have been reported by several groups in other tumors using H\&E staining and CD31/ CD34-PAS double staining (15,17,41-43). VM was present in 18 of 71 (25.4\%) cases by using H\&E and CD31-PAS double staining, which is different from other tumors, such as ovarian carcinoma (36.4\%) (13), breast cancer (7.9\%) (12) and HCC (19\%) (44). However, our results were similar to another report, such as LSCC (21.67\%) (15). Possible explanations for the discrepancy may be due to the different tissue origin, samples size and judgement criteria variable across labs. Moreover, we confirmed that $\mathrm{VM}$ was not specific to human primary GBC and it is not a rare pathological feature in GBC. We also found VM was significantly associated with histological type (adenocarcinoma) and liver infiltration suggesting that adenocarcinoma of GBC tend to form VM channels. In addition, as a functional channel and specific biological behavior of highly aggressive carcinoma, VM was favorable for hematogenous metastasis including liver infiltration in GBC patients with VM. To evaluate the relationship between VM and CD31-MVD, we then assessed the number of CD31-MVD in GBC samples with VM and non-VM group. Our data showed that the MVD of GBC samples was significantly higher in the non-VM group than that in the VM group. Work from several laboratories has revealed that VM was negatively correlated with MVD in several tumor types $(17,41,45,46)$. Our results, together with the previous reports, indicated that VM could convey blood plasma and red blood cells to satisfy the growth of tumor and hematogenous metastasis independent of angiogenesis and revealed that the tumors with VM could remain non-necrotic due to the blood flow in VM and VM-angiogenesis junction although MVD was less.

It has been demonstrated that rapamycin, as the HIF-1 $\alpha$ inhibitor, could prevent VM formation and phenotype transformation of the ovarian cancer cells SKOV3ip (47). Therefore, understanding the VM-related gene (HIF-1 $\alpha$ ) expression pattern in GBC patients would serve as an important target for new cancer therapies. Our data evidenced that overexpressed HIF-1 $\alpha$ was significantly associated with VM in GBC tissue samples. These findings coincide with previous studies that overexpression of HIF-1 $\alpha$ by IHC studies was seen in several tumors, including gastric adenocarcinoma (17) and melanoma (48), indicating that hypoxia could induce VM channel formation through the overexpression of HIF-1 $\alpha$ in human primary GBC. In light of the evidence presented by us, elevated HIF-1 $\alpha$ expression was correlated with the depth of invasion and perineural involvement in VM-negative group, and was not associated with any clinicopathological features in VM-positive group. Therefore, based upon the collective data it is reasonable to speculate that the elevated HIF-1 $\alpha$ expression might contribute to the development and progression of GBC patients with non-VM. However, no significant association between HIF-1 $\alpha$ expression and clinicopathological features was found in VM-positive group, probably due to the only 18 GBC patients with VM recruited in the current study. Additional investigation with a larger GBC patient population with VM in a multicenter study is needed before definitive conclusions can be drawn.

In multivariate analysis of Cox model, VM and HIF-1 $\alpha$ expression were also independent prognostic variables for OS in GBC patients. The data showed VM was related to decreased 5-year survival. In VM-negative group, low HIF-1 $\alpha$ expression in GBC patients was associated with better 5-year survival rate as compared with patients with high HIF-1 $\alpha$ expression, strongly suggesting that these two parameters may be useful as independent markers to identity a subset of GBC patients with more aggressive disease and may be predictors for the patient prognosis and survival. Hence, integration of VM and HIF-1 $\alpha$ into current models could result in more accurate survival prediction and may also be useful for individualizing follow-up and selection GBC patients with VM and non-VM for clinical trials.

In conclusion, HIF-1 $\alpha$ is the crucial mediator of VM formation of GBC cells. Furthermore, VM was present in human 
primary GBC. As a VM-related gene, increased HIF-10 expression was significantly associated with $\mathrm{VM}$, and also was correlated with tumor progression in non-VM GBC patients. In addition, VM and HIF-1 $\alpha$ expression were independent factors for OS of GBC patients and associated with poor prognosis. Hence, HIF-1 $\alpha$-targeted therapeutics may be useful for GBC patients. However, more cases need to be studied to verify our findings, especially in view of the uncertain results. Further investigations are warranted to elucidate the precise molecular cascade of HIF- $1 \alpha$ that regulates the pathogenesis of VM in GBC patients in vivo and in vitro for the development of effective treatment.

\section{Acknowledgements}

This study was supported by a grant from the National Nature Science Foundation of China (no. 30672073). We are grateful to Professors A.F. Fu and M.Z. Xi (Department of Pathology, Shanghai Jiaotong University, China) for their technical assistance of immunohistochemistry, western blotting and real-time RT-PCR analysis. We are grateful to Professors X.Y. Yu, H. $\mathrm{Xi}$ and H.B. Tong (Department of Pathology, Shanghai Tenth People's Hospital, Tongji University, China) for reviewing the tissue specimens.

\section{References}

1. Wistuba, II and Gazdar AF: Gallbladder cancer: lessons from a rare tumour. Nat Rev Cancer 4: 695-706, 2004.

2. Hsing AW, Sakoda LC, Rashid A, et al: Body size and the risk of biliary tract cancer: a population-based study in China. Br J Cancer 99: 811-815, 2008.

3. Hsing AW, Bai Y, Andreotti G, et al: Family history of gallstones and the risk of biliary tract cancer and gallstones: a population-based study in Shanghai, China. Int J Cancer 121: 832-838, 2007

4. Zhu AX, Hong TS, Hezel AF and Kooby DA: Current management of gallbladder carcinoma. Oncologist 15: 168-181, 2010.

5. Misra S, Chaturvedi A, Misra NC and Sharma ID: Carcinoma of the gallbladder. Lancet Oncol 4: 167-176, 2003.

6. Kuroki T, Tajima Y, Matsuo K and Kanematsu T: Genetic alterations in gallbladder carcinoma. Surg Today 35: 101-105, 2005.

7. Maniotis AJ, Folberg R, Hess A, et al: Vascular channel formation by human melanoma cells in vivo and in vitro: vasculogenic mimicry. Am J Pathol 155: 739-752, 1999.

8. Hendrix MJ, Seftor EA, Hess AR and Seftor RE: Molecular plasticity of human melanoma cells. Oncogene 22: 3070-3075, 2003.

9. Folberg R and Maniotis AJ: Vasculogenic mimicry. APMIS 112: 508-525, 2004

10. Hendrix MJC, Seftor EA, Hess AR and Seftor REB: Vasculogenic mimicry and tumour-cell plasticity: lessons from melanoma. Nat Rev Cancer 3: 411-421, 2003.

11. Vartanian AA, Stepanova EV, Gutorov SL, et al: Prognostic significance of periodic acid-Schiff-positive patterns in clear cell renal cell carcinoma. Can J Urol 16: 4726-4732, 2009.

12. Shirakawa K, Wakasugi H, Heike Y, et al: Vasculogenic mimicry and pseudo-comedo formation in breast cancer. Int J Cancer 99: 821-828, 2002

13. Sood AK, Fletcher MS, Zahn CM, et al: The clinical significance of tumor cell-lined vasculature in ovarian carcinoma: implications for anti-vasculogenic therapy. Cancer Biol Ther 1: 661-664 2002.

14. Sun B, Zhang S, Zhang D, et al: Vasculogenic mimicry is associated with high tumor grade, invasion and metastasis, and short survival in patients with hepatocellular carcinoma. Oncol Rep 16: 693-698, 2006.

15. Wang W, Lin P, Han C, Cai W, Zhao X and Sun B: Vasculogenic mimicry contributes to lymph node metastasis of laryngeal squamous cell carcinoma. J Exp Clin Cancer Res: 29, 2010.
16. El Hallani S, Boisselier B, Peglion F, et al: A new alternative mechanism in glioblastoma vascularization: tubular vasculogenic mimicry. Brain 133: 973-982, 2010.

17. Li M, Gu Y, Zhang Z, et al: Vasculogenic mimicry: a new prognostic sign of gastric adenocarcinoma. Pathol Oncol Res 16: 259-266, 2010.

18. Baeten CI, Hillen F, Pauwels P, de Bruine AP and Baeten CG: Prognostic role of vasculogenic mimicry in colorectal cancer. Dis Colon Rectum 52: 2028-2035, 2009.

19. Sun BC, Zhang SW, Zhao XL and Hao XS: Vasculogenic mimicry is associated with shorter survival in hepatocellular carcinomas. Lab Invest 86: 1302, 2006.

20. Ke Q and Costa M: Hypoxia-inducible factor-1 (HIF-1). Mol Pharmacol 70: 1469-1480, 2006.

21. Mooring SR and Wang B: HIF-1 inhibitors as anti-cancer therapy. Science China Chem 54: 24-30, 2011.

22. Bissell MJ: Tumor plasticity allows vasculogenic mimicry, a novel form of angiogenic switch. A rose by any other name? Am J Pathol 155: 675-679, 1999.

23. Wang L, Wang P, Ding Z, et al: Effect of HIF-1 alpha gene silence on the expression of vasculogenic mimicry associated genes in esophageal squamous cancer in vivo. Acta Universitatis Medicinalis Nanjing 31: 314, 2011.

24. Shi R, Jin H-l and Zhang H-J: Effect of RNA interference targeting for HIF-1 alpha on vasculogenic mimicry in esophageal squamous cell carcinoma. Gastroenterology 140 (Suppl 1): S827, 2011.

25. Comito G, Calvani M, Giannoni E, et al: HIF-1 alpha stabilization by mitochondrial ROS promotes Met-dependent invasive growth and vasculogenic mimicry in melanoma cells. Free Radic Biol Med 51: 893-904, 2011.

26. Vartanian AA, Burova OS, Stepanova EV, Baryshnikov AY and Lichinitser MR: Melanoma vasculogenic mimicry is strongly related to reactive oxygen species level. Melanoma Res 17: 370-379, 2007.

27. Sun BC, Zhang DF, Zhang SW, Zhang WZ, Guo H and Zhao XL: Hypoxia influences vasculogenic mimicry channel formation and tumor invasion-related protein expression in melanoma. Cancer Lett 249: 188-197, 2007.

28. van der Schaft DW, Hillen F, Pauwels P, et al: Tumor cell plasticity in Ewing sarcoma, an alternative circulatory system stimulated by hypoxia. Cancer Res 65: 11520-11528, 2005.

29. Chen Y, Jiang L, She F, Tang N, Wang X, Li X, Han S and Zhu J: Vascular endothelial growth factor-C promotes the growth and invasion of gallbladder cancer via an autocrine mechanism. Mol Cell Biochem 345: 77-89, 2010.

30. Zong HJ, Yin BB, Chen JH, Ma BJ, Cai D and He XH: OverExpression of c-FLIP confers the resistance to TRAIL-induced apoptosis on gallbladder carcinoma. Tohoku J Exp Med 217: 203-208, 2009 .

31. Sun W, Fan YZ, Zhang WZ and Ge CY: A pilot histomorphology and hemodynamic of vasculogenic mimicry in gallbladder carcinomas in vivo and in vitro. J Exp Clin Cancer Res: 30, $1-12,2011$.

32. Shi Y, Chang M, Wang F, Ouyang X, Jia Y and Du H: Role and mechanism of hypoxia-inducible factor-1 in cell growth and apoptosis of breast cancer cell line MDA-MB-231. Oncol Lett 1: 657-662, 2010.

33. Batmunkh E, Shimada M, Morine Y, et al: Expression of hypoxia-inducible factor-1 alpha (HIF-1 alpha) in patients with the gallbladder carcinoma. Int J Clin Oncol 15: 59-64, 2010.

34. Nadaoka J, Horikawa Y, Saito M, et al: Prognostic significance of HIF-1 alpha polymorphisms in transitional cell carcinoma of the bladder. Int J Cancer 122: 1297-1302, 2008.

35. Zlobec I, Steele R, Terracciano L, Jass JR and Lugli A: Selecting immunohistochemical cut-off scores for novel biomarkers of progression and survival in colorectal cancer. J Clin Pathol 60: 1112-1116, 2007.

36. Postovit LM, Margaryan NV, Seftor EA and Hendrix MJ: Role of nodal signaling and the microenvironment underlying melanoma plasticity. Pigment Cell Melanoma Res 21: 348-357, 2008.

37. Folberg R, Arbieva Z, Moses J, et al: Tumor cell plasticity in uveal melanoma: microenvironment directed dampening of the invasive and metastatic genotype and phenotype accompanies the generation of vasculogenic mimicry patterns. Am J Pathol 169: 1376-1389, 2006.

38. Ma JL, Han SX, Zhu Q, Zhao J, Zhang D, Wang L and Lv Y: Role of Twist in vasculogenic mimicry formation in hypoxic hepatocellular carcinoma cells in vitro. Biochem Biophys Res Commun 408: 686-691, 2011. 
39. Zhang SW, Zhang DF and Sun BC: Vasculogenic mimicry: current status and future prospects. Cancer Lett 254: 157-164, 2007.

40. Chen LX, He YJ, Zhao SZ, et al: Inhibition of tumor growth and vasculogenic mimicry by curcumin through down-regulation of the EphA2/PI3K/MMP pathway in a murine choroidal melanoma model. Cancer Biol Ther 11: 229-235, 2011.

41. Xu X, Jia R, Zhou Y, Song X and Fan X: Investigation of vasculogenic mimicry in sebaceous carcinoma of the eyelid. Acta Ophthalmol 88: e160-164, 2010.

42. Zhang SW, Li M, Gu YJ, et al: Thalidomide influences growth and vasculogenic mimicry channel formation in melanoma. $\mathrm{J}$ Exp Clin Cancer Res 27: 1-9, 2008.

43. Han C, Sun B, Wang W, et al: Overexpression of microtubuleassociated protein-1 light chain 3 is associated with melanoma metastasis and vasculogenic mimicry. Tohoku J Exp Med 223: 243-251, 2011
44. Sun T, Zhao N, Zhao XL, et al: Expression and functional significance of Twist1 in hepatocellular carcinoma: its role in vasculogenic mimicry. Hepatology 51: 545-556, 2010.

45. Ahmadi SA, Moinfar M, Gohari Moghaddam K and Bahadori M: Practical application of angiogenesis and vasculogenic mimicry in prostatic adenocarcinoma. Arch Iran Med 13: 498-503, 2010.

46. Sun BC, Qie S, Zhang SW, et al: Role and mechanism of vasculogenic mimicry in gastrointestinal stromal tumors. Human Pathol 39: 444-451, 2008

47. Su M, Feng YJ, Yao LQ, et al: Plasticity of ovarian cancer cell SKOV3ip and vasculogenic mimicry in vivo. Int $\mathrm{J}$ Gynecol Cancer 18: 476-486, 2008. 